\title{
Evolution of binding affinity in a WW domain probed by phage display
}

\author{
PAUL A. DALBY, ${ }^{1}$ RONALD H. HOESS,${ }^{2}$ AND WILLIAM F. DEGRADO ${ }^{3}$ \\ ${ }^{1}$ Department of Biochemical Engineering, University College London, London WC1E 7JE, United Kingdom \\ ${ }^{2}$ DuPont Pharmaceuticals, Building 336/205, Wilmington, Delaware 19880 \\ ${ }^{3}$ Department of Biochemistry and Biophysics, University of Pennsylvania, Philadelphia, Pennsylvania 19104
}

(Received June 12, 2000; Final Revision August 31, 2000; AccePted October 3, 2000)

\begin{abstract}
The WW domain is an approximately 38 residue peptide-binding motif that binds a variety of sequences, including the consensus sequence XPPxY. We have displayed hYAP65 WW on the surface of M13 phage and randomized one-third of its three-stranded antiparallel $\beta$-sheet. Improved binding to the hydrophobic peptide, GTPPPPYTVG (WW1), was selected in the presence of three different concentrations of proteinase $\mathrm{K}$ to simultaneously drive selection for improved stability as well as high-affinity binding. While some of the selected binders show cooperative unfolding transitions, others show noncooperative thermal unfolding curves. Two novel WW consensus sequences have been identified, which bind to the XPPXY motif with higher affinity than the wild-type hYAP65 WW domain. These WW domain sequences are not precedented in any natural WW domain sequence. Thus, there appear to be a large number of motifs capable of recognizing the target peptide sequence, only a subset of which appear to be used in natural proteins.
\end{abstract}

Keywords: cooperativity; peptide binding; phage display; protein scaffold; specificity; stability; WW domain

An ever-increasing number of cellular processes have been shown to involve protein-protein interactions. However, these interactions are mediated by relatively few protein binding modules of which Src homology region 2 (SH2), Src homology region 3 (SH3), pleckstrin homology (PH), PDZ, phosphotyrosine-binding (PTB), WW domains, and forkhead-associated (FHA) domains, have been characterized most extensively (Pawson \& Scott, 1997; Sudol, 1998; Liao et al., 1999). Each of these domains generally demonstrates a unique binding specificity. For example, the $\mathrm{SH} 2$ domain binds to ligands containing a phosphotyrosine residue followed by a hydrophobic residue at position +3 (Zhou \& Cantley, 1995), whereas SH3 domains recognize sequences containing a PXXP motif, typically RXФPXXP and PXФPXR ( $\mathrm{X}$ is any amino acid, $\Phi$ is a hydrophobic residue) (Feng et al., 1994; Lim et al., 1994). The WW domain, however, has already been shown to recognize at least five distinct binding motifs. As a result, WW domains are now being classified according to their binding specificity (Espanel $\&$ Sudol, 1999). The so-called group I WW domains recognize sequences of the type PPXY, and examples include the human

Reprint requests to: William F. DeGrado, Department of Biochemistry and Biophysics, University of Pennsylvania, School of Medicine, Philadelphia, Pennsylvania 19104; e-mail: wdegrado@mail.med.upenn.edu.

Abbreviations: WW, Trp-Trp domain; CD, circular dichroism; hYAP, human Yes associated protein; GST, glutathione-S-transferase; SDS-PAGE, sodium dodecylsulfate polyacrylamide gel electrophoresis; WW1, peptide with the sequence GTPPPPYTVG; SIP, selectively infective phage; PK, proteinase K; SubA, subtilisin A; MALDI-TOF, matrix-assisted laser desorption ionization-time of flight; ES, electrospray.
Yes-associated protein (hYAP) WW domains, WWP1 (a ubiquitin ligase homologue), and Nedd4 (Linn et al., 1997; Mosser et al., 1998; Lu et al., 1999). Group II WW domains bind to sequences containing stretches of prolines interspersed by an occasional leucine residue (PPLP motif), for example, the WW domain of the neural protein FE65 binds a PPLP sequence contained in the Mena protein (Ermekova et al., 1997). Group III WW domains, such as FBP21 (Bedford et al., 1998), recognize stretches of proline residues that are also rich in methionine and glycine (PGM motif). Group IV WW domains, such as PIN1 and again Nedd4, bind to sequences containing a phosphoserine or phosphothreonine (Lu et al., 1999). Finally, group V WW domains, which include FBP30 but also again FE65 and FBP21, recognize stretches of proline residues that are rich in arginine (Pro-Arg motif) (Bedford et al., 2000).

Four structures of WW domains, from hYAP (NMR), PIN1 (X-ray), FBP28 (NMR), and YJQ8 (NMR) have been determined (Macias et al., 1996, 2000; Ranganathan et al., 1997). The four structures are very similar, comprising a small (ca. 34-38 residue) three-stranded antiparallel $\beta$-sheet, which presents a cup-shaped binding surface. The structure of the hYAP WW domain was obtained with the ten-residue polypeptide GTPPPPYTVG, complexed to the concave face of the $\beta$-sheet. This polypeptide sequence was isolated using a functional screen of an expressed mouse cDNA library (Chen \& Sudol, 1995).

A recent study has shown that a single point mutation (L190W) in the group I WW domain of hYAP shifts its specificity to mimic that of the group II WW domain of FE65 (Espanel \& Sudol, 1999). 
The specificity of the group II WW domains thus appears to be determined by three consecutive aromatic residues in the second $\beta$-strand of the WW domain. Their search for a shift in specificity was, however, limited to saturation mutagenesis of just two amino acid positions, both of which interact directly with the tyrosine residue of the PPxY motif. In this study, we have constructed a phage-display library of the WW domain from hYAP, containing eight randomized residues. This library was used, in part, to select for the optimal WW domain sequence that binds to the probe peptide GTPPPPYTVG. Our results show that the wild-type YAP WW is not optimized for tight binding to the PPPPY sequence. Instead, we found that two potential previously unidentified WW consensus sequences bind with up to 56-fold higher affinity to the probe.

Due to its small size, the binding of the WW domain to its ligand is likely to be heavily influenced by the folding and stability of the WW domain. To probe this possibility, we used the same phage library to select for GTPPPPYTVG binding in the presence of increasing concentrations of proteinase $\mathrm{K}$, a method used previously to select for the improved stability of a protein (Kristensen \& Winter, 1998; Finucane \& Woolfson, 1999; Jung et al., 1999).

\section{Results}

Residues E6 to S57 of the three-stranded antiparallel $\beta$-sheet of the WW domain of hYAP65 (human Yes associated protein) were displayed on the N-terminus of the gene III coat protein of M13PL9 bacteriophage (Fig. 1). Eight contiguous residues (Y28 to Q35), which comprise one-third of the entire $\beta$-sheet, were fully randomized in a library that represents $1 \%$ of all possible permutations (Fig. 1). The chosen residues contribute significantly to both the stability of the WW domain and to the ligand binding properties of the protein (Macias et al., 1996). Residues Y28 to N31 form the majority of the central $\beta$-strand (Fig. 2), while residues H32, I33, D34, and Q35 approximate a $\alpha_{r}-\alpha_{r}-\alpha_{r}-\alpha_{L}$ loop ( $\pi$-turn motif) (Rajashankar \& Ramakumar, 1996; Gunasekaran et al., 1997) joining strand 2 to residue T36 in the third $\beta$-strand. Residue F29 is involved in an important hydrophobic contact with I7, which, in turn, contacts P14 and P42, to form the hydrophobic core. Residues Y28, L30, and H32, along with the nonrandomized W39 and $\mathrm{T} 37$, form the hydrophobic binding patch on the opposite face of the $\beta$-sheet. The structure of the WW domain in complex with the peptide WW1 (GTPPPPYTVG) has been determined previously (Macias et al., 1996). Residues L30, H32, and possibly Q35 make
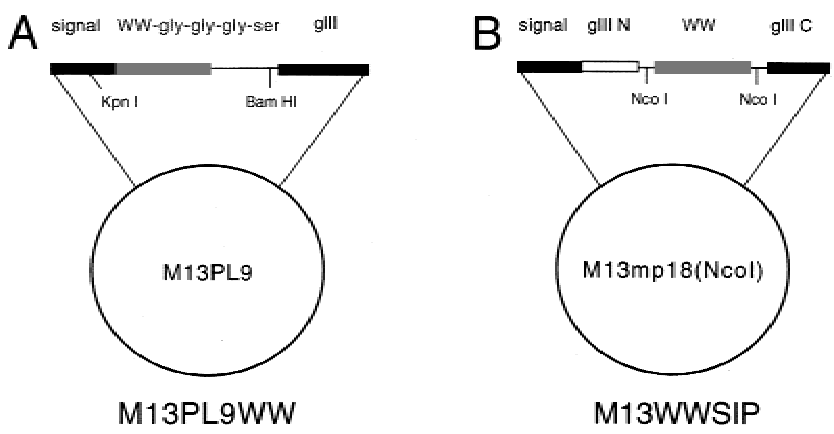

Fig. 1. Construction of (A) the M13WWPL9 vector and (B) the M13WWSIP vector.
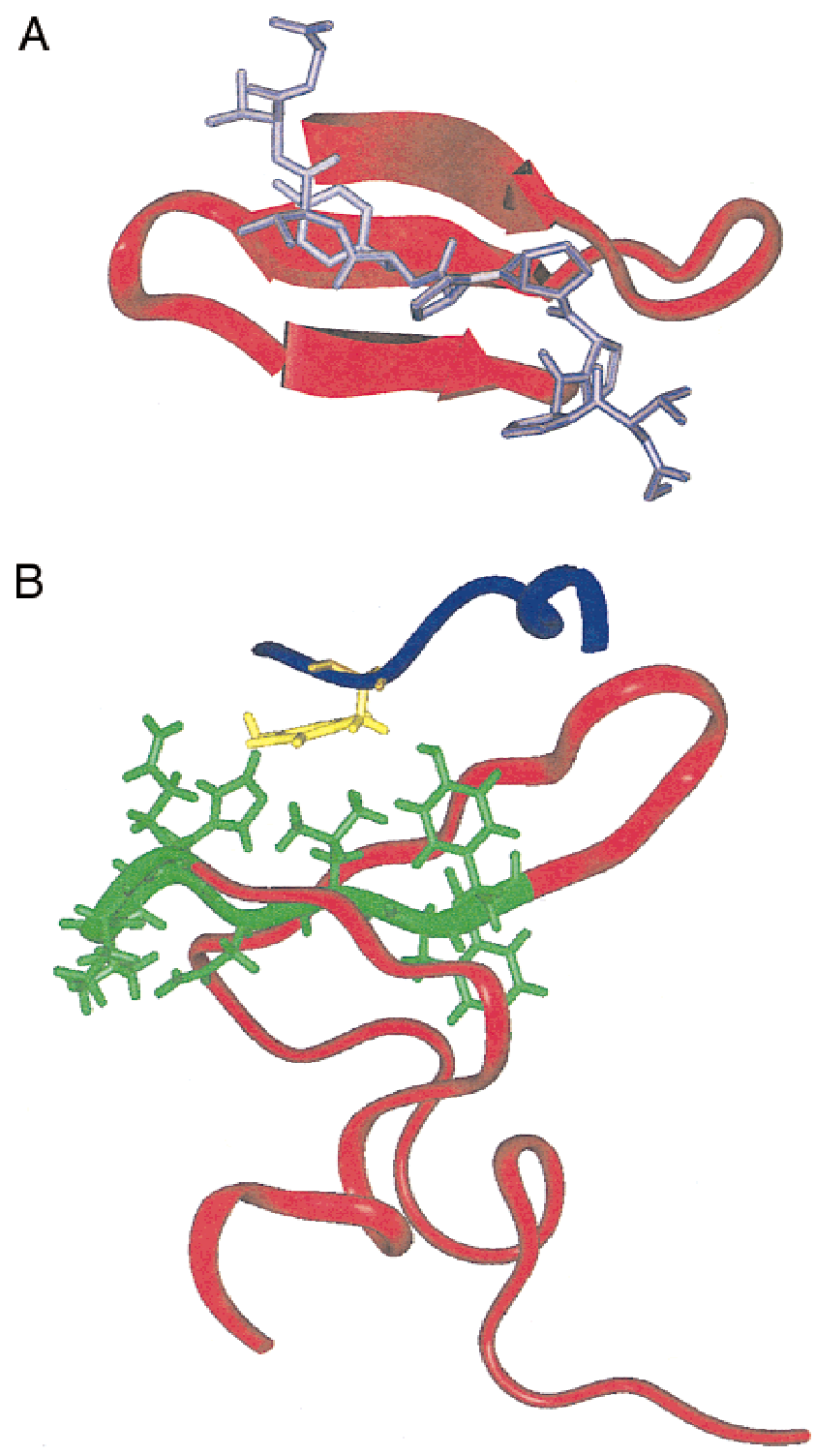

Fig. 2. Structure of the wild-type WW domain bound to WW1 peptide. A: Top view, with WW1 shown in light blue, and the WW domain shown in red. B: Side view, with the eight randomized residues shown in green. The WW1 peptide is shown in blue, with the peptide tyrosine residue in yellow.

contacts with the peptide tyrosyl residue $\mathrm{Y7}^{\prime}$, while residue Y28 forms a hydrogen bond to the carbonyl group of $\mathrm{P}^{\prime}$. The library of WW domains was designed, therefore, to provide a selection for improved binding as well as stability.

To select for binding to the WW1 peptide, it was first immobilized on a streptavidin coated well, using EZ-link ${ }^{\mathrm{TM}}$, an N-hydroxysuccinimidyl ester derivative of biotin (NHS-SS-Biotin, Pierce, Rockford, Illinois). This allowed the peptide to be displayed up to $24 \AA$ away from the streptavidin protein surface. Furthermore, the linker contained a disulfide bond, which allowed us to specifically elute the phage that interacted with the peptide, using dithiothreitol (DTT) (Fig. 3).

To select for thermodynamic stability of the WW domain while retaining its WW1 binding properties, a short wash with a protease 


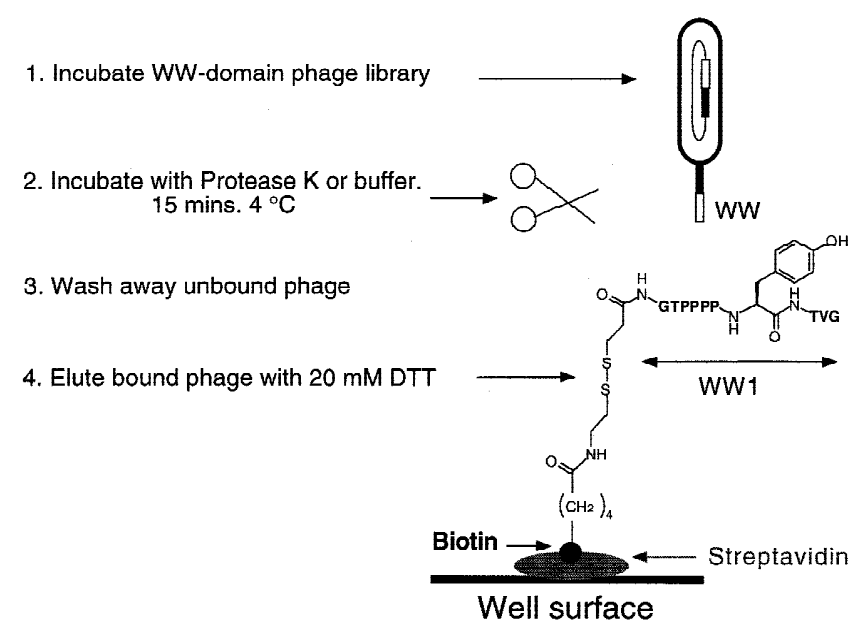

Fig. 3. Biopanning against the WW1 peptide. WW1 is biotinylated using EZ-link $^{\mathrm{TM}}$ (Pierce) and immobilized on a streptavidin coated well surface. Captured phage are incubated with $0,0.013$, or $0.13 \mu \mathrm{g} / \mathrm{mL}$ proteinase $\mathrm{K}$, $50 \mathrm{mM}$ Tris $\cdot \mathrm{Cl}, 100 \mathrm{mM} \mathrm{NaCl}, 2 \mathrm{mM} \mathrm{Ca}(\mathrm{OAc})_{2}, \mathrm{pH}$ 8.0, washed eight times then eluted specifically by incubating with $20 \mathrm{mM}$ reduced DTT.

was included in the selection step (Kristensen \& Winter, 1998; Finucane \& Woolfson, 1999; Jung et al., 1999). Several proteases were evaluated using a second phage, M13WWSIP, which contained the WW domain fused between the $\mathrm{N}$ - and C-terminal domains of the geneIII protein (pIII) of M13mp18 (Fig. 1B). The $\mathrm{N}$-terminal domain of $\mathrm{pIII}$ is essential for the infection of Escherichia coli by M13 bacteriophage (Krebber et al., 1997). Therefore, proteolysis within the new selectively infective phage (SIP) construct leads to a noninfective phage particle.

The M13WWSIP phage and the wild-type phage (M13mp18), both in the presence and absence of $100 \mu \mathrm{M} \mathrm{WW1,} \mathrm{were} \mathrm{incubated}$ for 15 min at $4{ }^{\circ} \mathrm{C}$, with either $\mathrm{ddH}_{2} \mathrm{O}$, proteinase $\mathrm{K}(\mathrm{PK})$, papain,

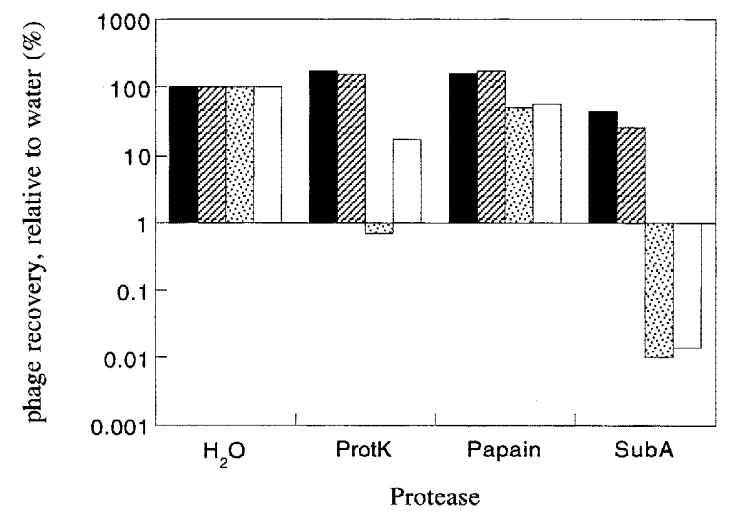

Fig. 4. Effect on recovery of $10 \times 10^{12} \mathrm{pfu} / \mathrm{mL}$ phage incubated with different proteases for $15 \mathrm{~min}$ at $4{ }^{\circ} \mathrm{C}$. (Solid) M13mp18 phage incubated with protease or water. (Hatched) M13mp18 phage incubated with $100 \mu \mathrm{M}$ WW1 peptide, and protease or water. (Spotted) M13WWSIP phage incubated with protease or water. (Blank) M13WWSIP phage incubated with $100 \mu \mathrm{M}$ WW1 peptide, and protease or water. ProtK contains $0.13 \mu \mathrm{g} / \mathrm{mL}$ proteinase $\mathrm{K}, 50 \mathrm{mM}$ Tris $\cdot \mathrm{Cl}, 100 \mathrm{mM} \mathrm{NaCl}, 2 \mathrm{mM} \mathrm{Ca}(\mathrm{OAc})_{2}$, $\mathrm{pH} 8.0$. Papain contains $0.147 \mu \mathrm{g} / \mathrm{mL}$ papain, $50 \mathrm{mM}$ glutamic acid, $100 \mathrm{mM}$ $\mathrm{NaCl}, 1 \mathrm{mM} \mathrm{CaCl} 2$, pH 6.6. SubA contains $100 \mu \mathrm{g} / \mathrm{mL}$ subtilisin A, $50 \mathrm{mM}$ Tris. $\mathrm{Cl}, 100 \mathrm{mM} \mathrm{NaCl}, 1 \mathrm{mM} \mathrm{CaCl}$, $\mathrm{pH}$ 7.5. or subtilisin A (SubA) (Fig. 4). The percent of phage recovered was normalized to the $\mathrm{ddH}_{2} \mathrm{O}$ experiment, as each protease required very different buffers. SubA was not a useful protease, as it digests both M13WWSIP and the wild-type M13mp18. Papain did not affect $\mathrm{M} 133 \mathrm{mp} 18$, but reduced the recovery of M13WWSIP to around $50 \%$ (relative to $\mathrm{ddH}_{2} \mathrm{O}$ ). However, the addition of $100 \mu \mathrm{M}$ WW1 did not influence the recovery of M13WWSIP. Finally, PK showed the same nondigestion behavior as papain toward the wild-type M13mp18 phage, but the recovery of M13WWSIP was only $0.7 \%$ in the absence of WW1. This recovery is markedly improved to $17 \%$ upon addition of $100 \mu \mathrm{M}$ WW1. The experiment was repeated for PK, at increasing concentrations of WW1. Figure 5 shows that the increase in recovery of the M13WWSIP phage does not occur until the WW1 peptide concentration reached $100 \mu \mathrm{M}$, approaching the dissociation constant for binding (see within). Thus, the binding of the WW1 peptide increases the global stability of the WW domain, thereby increasing its resistance to PK.

\section{Biopanning with increasing $P K$ concentrations}

The library of WW domains was panned against immobilized peptide WW1 (Fig. 3), including a 15 min pulse, at $4{ }^{\circ} \mathrm{C}$, of one of three different PK concentrations. The changes in phage recovery after each of six rounds of biopanning are shown in Figure 6. At all three concentrations of PK, the libraries converge by round 6 , at approximately a 100 -fold increase in recovery. One subtle trend is in the round at which the recovery increase is first observed. In the absence of PK, the increase in recovery converges at round 5 . In the presence of the highest concentration of PK $(0.13 \mu \mathrm{g} / \mathrm{mL})$, the increase in recovery converges at round 4 . This trend suggests that the proteinase $\mathrm{K}$ adds to the overall selection pressure, forcing an earlier elimination of background binding and an earlier convergence of binding species. The sequences of the mutants obtained from round six are shown in Table 1. Clones containing identical amino acid sequences were always encoded by identical DNA sequences, suggesting that multiply isolated clones were siblings.

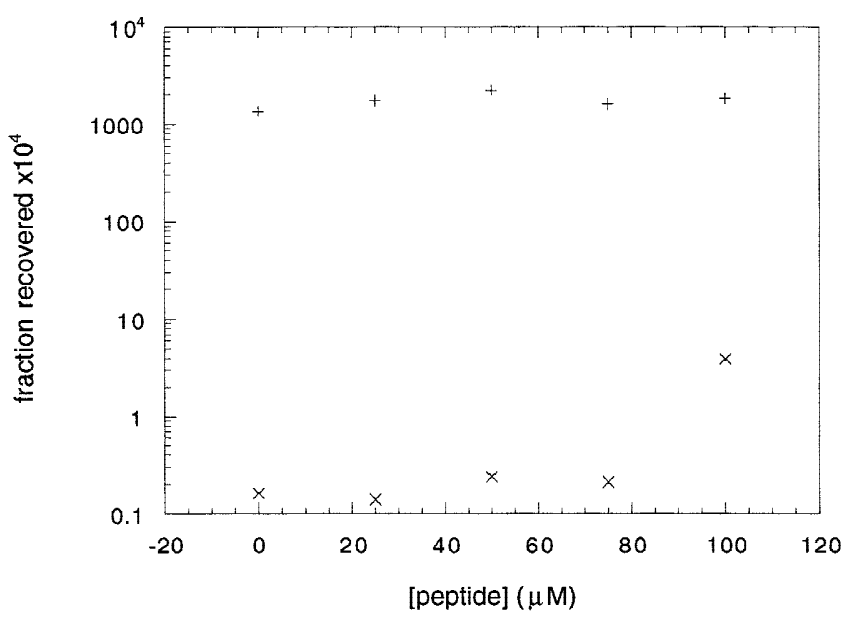

Fig. 5. Effect of titration of WW1 peptide on recovery of $10 \times 10^{12}$ $\mathrm{pfu} / \mathrm{mL}$ M13WWSIP phage $(\times)$ or M13mp18 phage $(+)$, incubated with $0.13 \mu \mathrm{g} / \mathrm{mL}$ proteinase $\mathrm{K}, 50 \mathrm{mM}$ Tris. $\mathrm{Cl}, 100 \mathrm{mM} \mathrm{NaCl}, 2 \mathrm{mM}$ $\mathrm{Ca}(\mathrm{OAc})_{2}, \mathrm{pH} 8.0$ for $15 \mathrm{~min}$ at $4{ }^{\circ} \mathrm{C}$. 


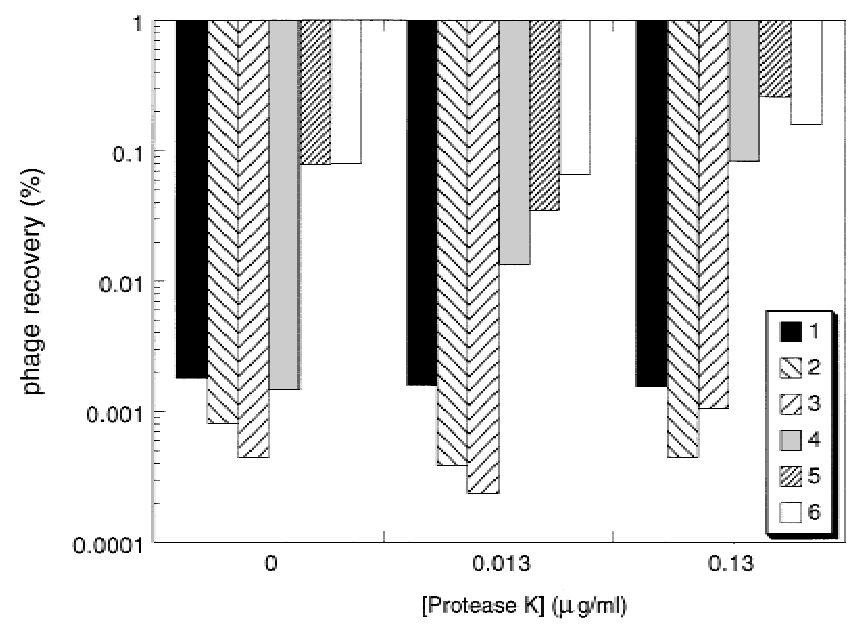

Fig. 6. Changes in the recovery of phage, for six rounds of biopanning against WW1, with exposure to increasing concentrations of proteinase $\mathrm{K}$, for 15 min at $4{ }^{\circ} \mathrm{C}$.

\section{Expression and purification of WW mutants}

All mutants of the WW domain were overexpressed as GST fusion proteins and purified as described in Materials and methods, except mutant 2 . This mutant gave two closely running bands in the 3 to $6 \mathrm{kDa}$ region of an SDS-PAGE gel, after cleavage of the GST fusion with thrombin, suggesting that the new sequence is susceptible to thrombin cleavage.

\section{Circular dichroism spectra}

The far-UV CD spectra of wild-type WW and the mutants are shown in Figure 7. The spectrum of wild-type WW has been characterized previously (Koepf et al., 1999) and is thought to represent an ensemble of $\beta$-sheet and random coil, with a mini-

Table 1. Sequences obtained from the sixth round of biopanning, for all three proteinase $K$ concentrations

\begin{tabular}{lllc}
\hline \hline Clone & \multicolumn{1}{c}{ Sequence $^{\mathrm{a}}$} & $\begin{array}{c}{[\mathrm{PK}]} \\
(\mu \mathrm{g} / \mathrm{mL})^{\mathrm{b}}\end{array}$ & $\begin{array}{c}\text { Number of } \\
\text { clones }^{\mathrm{c}}\end{array}$ \\
\hline wt & YFLNHIDQ & & \\
1 & WFEGWRWG & 0 & 2 \\
2 & WAWSQPRW & 0 & 2 \\
3 & GSFWFDRW & 0 & 2 \\
PK1 & GSFWFDRW & 0.013 & 2 \\
PK2 & GWWHGREW & 0.013 & 6 \\
PK3 & WRDSWPQW & 0.013 & 2 \\
PK4 & SGFRERFW & 0.13 & 2 \\
\hline \hline
\end{tabular}

\footnotetext{
${ }^{\text {a }}$ Sequence of residues 28 to 35 of the WW domain.

${ }^{\mathrm{b}}$ Concentration of proteinase $\mathrm{K}$ in $50 \mathrm{mM}$ Tris $\cdot \mathrm{Cl}, 100 \mathrm{mM} \mathrm{NaCl}, 2 \mathrm{mM}$ $\mathrm{Ca}(\mathrm{OAc})_{2}, \mathrm{pH} 8.0$, added for $15 \mathrm{~min}$ at $4^{\circ} \mathrm{C}$.

${ }^{\mathrm{c}}$ Number of mutants with given sequence. Ten clones were sequenced from each experiment. The clones not shown contained deletions of the WW domain region.
}

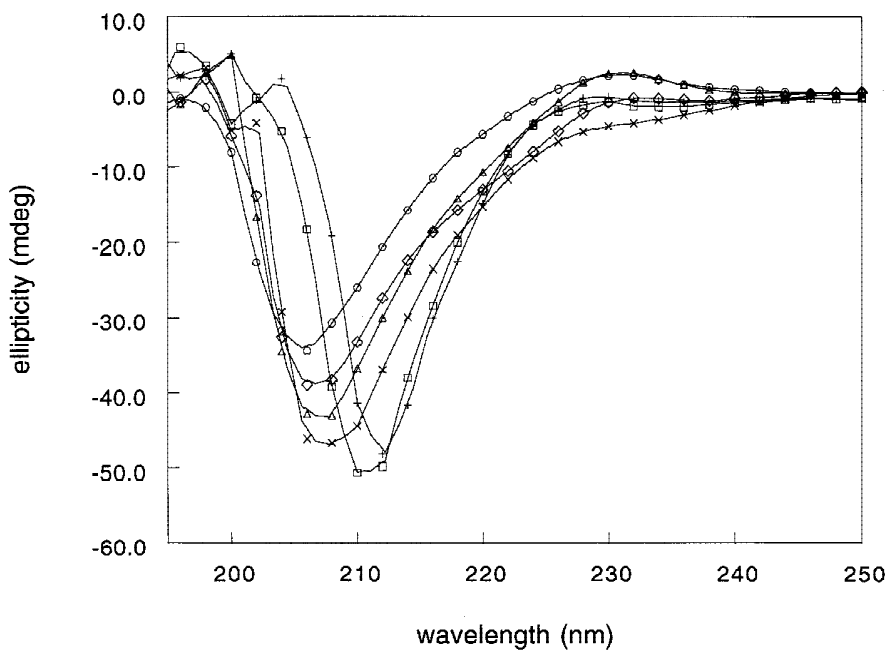

Fig. 7. Far-UV CD spectra of $50 \mu \mathrm{M}$ of the WW domains in buffer $\mathrm{A}$, pH 6.0. Wild-type WW (o), mutant 1 (squares), mutant 3 (also PK1) (diamonds), mutant PK2 $(\times)$, mutant PK3 (crosses), and mutant PK4 (triangles).

mum at $\sim 206 \mathrm{~nm}$ and a positive ellipticity maximum at $\sim 232 \mathrm{~nm}$ (Fig. 7). The spectra of the mutants $3 / \mathrm{PK} 1$ and PK4 share these characteristics. By contrast, mutants PK2, 1, and PK3 show a minimum at increasingly longer wavelengths of 208, 210, and $212 \mathrm{~nm}$, respectively, possibly indicative of increasing content of $\beta$-structure. Further, the PK2 lacks a clear maximum near $232 \mathrm{~nm}$ in its spectrum. Interestingly, mutants $1, \mathrm{PK} 2$, and PK3 also failed to show cooperative unfolding transitions (see below; Table 2).

\section{Fluorescence spectra}

Wild-type WW has a maximum fluorescence emission at $\sim 341 \mathrm{~nm}$, indicative of partially exposed Trp side chains. Mutants 3/PK1 and PK4, which showed CD spectra closest to the wild-type, similarly resemble the wild-type in their fluorescence spectra (Table 2). By contrast, mutants 1, PK2, and PK3 all show a maximum emission redshifted to $\sim 355 \mathrm{~nm}$. These mutants also contain a larger number of Trp residues along their binding face. The longer wavelength is indicative of more solvent exposed tryptophan residues (the emission maximum for $\mathrm{N}$-acetyl-tryptophan in $20 \mathrm{mM}$ phosphate buffer, $\mathrm{pH} 7.0$, is at $355 \mathrm{~nm}$ (Lakshmikanth \& Krishnamoorthy, 1999)). The mutants 1 , PK2, and PK3 display fluorescence emission maxima similar to the wild-type WW domain, even though they contain three additional tryptophan residues. This suggests that on average, the tryptophan residues have similar solventexposure in mutants 3, PK1, PK4, and the wild-type protein, but are nearly fully exposed in the mutants $1, \mathrm{PK} 2$, and PK3.

\section{Dissociation constants $\left(K_{d}\right)$ for the binding of NAcWWI to the WW domains}

The binding of XPPxY ligands to the wild-type WW domain results in an enhanced fluorescence emission of the protein (Koepf et al., 1999). This behavior was expected to extend to our WW mutants, since they all contain the two wild-type tryptophans, plus one to three more on the binding surface. Although mutants PK2, PK3, and PK4 gave similar increases in fluorescence to wild-type upon 
Table 2. Summary of dissociation constants $\left(K_{d}\right)$, approximate change in $T_{m}$, and cooperativity of unfolding

\begin{tabular}{|c|c|c|c|c|c|c|c|c|}
\hline Clone & $\begin{array}{l}\text { \# Trp } \\
\text { residues }^{\text {a }}\end{array}$ & $\begin{array}{c}{[\mathrm{PK}]} \\
(\mu \mathrm{g} / \mathrm{mL})^{\mathrm{b}}\end{array}$ & $\begin{array}{c}K_{d} \\
(\mu \mathrm{M})^{\mathrm{c}}\end{array}$ & 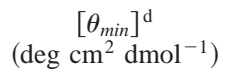 & $\begin{array}{l}\lambda_{\max }{ }^{\mathrm{e}} \\
(\mathrm{nm})\end{array}$ & $\begin{array}{l}\Delta T_{m} \\
\left({ }^{\circ} \mathrm{C}\right)^{\mathrm{f}}\end{array}$ & $\begin{array}{l}\text { Cooperative } \\
\text { unfolding? }\end{array}$ & $\begin{array}{c}\text { Consensus } \\
\text { type }^{g}\end{array}$ \\
\hline wt & 1 & n.a. ${ }^{\mathrm{h}}$ & $188 \pm 4$ & 206 & 341 & 0 & Yes & \\
\hline 1 & 3 & 0 & n.d. ${ }^{\mathrm{i}}$ & 210 & 355 & n.a. & No & A \\
\hline 2 & 4 & 0 & n.d. & & & n.d. & n.d. & $\mathrm{A} / \mathrm{B}$ \\
\hline 3 & 2 & 0 & $102 \pm 21$ & 207 & 346 & 0 & Yes & B \\
\hline PK1 & 2 & 0.013 & $102 \pm 21$ & 207 & 346 & 0 & Yes & B \\
\hline \multirow[t]{2}{*}{ PK2 } & 3 & 0.013 & $37 \pm 16$ & 208 & 359 & n.a. & No & B \\
\hline & 4 & 0.013 & $3.3 \pm 1.3$ & 212 & 355 & n.a. & No & A \\
\hline PK4 & 2 & 0.13 & $98 \pm 9$ & 207 & 341 & 2.0 & Yes & B \\
\hline
\end{tabular}

${ }^{\mathrm{a}}$ The number of Trp residues along the binding surface of the WW domain, at positions 28, 32, 35, 39.

${ }^{\mathrm{b}}$ Concentration of proteinase $\mathrm{K}$ in $50 \mathrm{mM}$ Tris $\cdot \mathrm{Cl}, 100 \mathrm{mM} \mathrm{NaCl}, 2 \mathrm{mM} \mathrm{Ca}(\mathrm{OAc})_{2}, \mathrm{pH} 8.0$, added for $15 \mathrm{~min}$ at $4{ }^{\circ} \mathrm{C}$.

${ }^{\mathrm{c}}$ Dissociation constant, determined by titration of $5 \mu \mathrm{M}$ WW domain, with NAcWW1, and monitored by fluorescence in buffer A, pH 6.0 (Fig. 10).

${ }^{\mathrm{d}}$ Position of minimum ellipticity in the CD spectrum.

${ }^{\mathrm{e}}$ Wavelength of maximum emission intensity in fluorescence spectrum, uncorrected for the wavelength dependence of the photomultiplier response.

${ }^{\mathrm{f}}$ Approximate change in mid-point temperature for thermal unfolding, relative to wild-type, in buffer A, $\mathrm{pH} 6.0$, where $\Delta T_{m}=$ $T_{m}^{\text {mutant }}-T_{m}^{w t}$

${ }^{\mathrm{g}}$ The type of consensus sequence described in Figure 10

${ }^{\mathrm{h}}$ n.a., not applicable.

${ }^{i}$ n.d., not determined.

binding NAcWW1, the mutant 3/PK1 produced a decrease in the fluorescence emission, and mutant 1 produced no observable change in fluorescence at all.

The fluorescence data for the titration of NAcWW1 into the WW domains, normalized to positive values, are shown in Figure 8 . All of the mutants have lower dissociation constants than that of the wild-type WW (Table 2). The mutant with CD and spectral properties most similar to wild-type, mutant 3 (also PK1), had the lowest affinities with a dissociation constant of $102 \mu \mathrm{M}$.

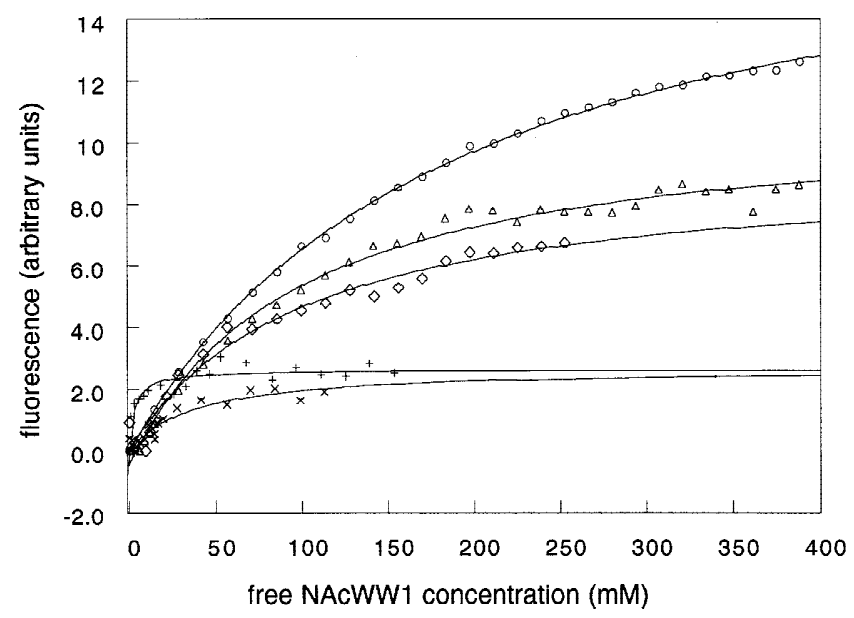

Fig. 8. Titration of $5 \mu \mathrm{M}$ wild-type WW (o), mutant 3 (also PK1) (diamonds), mutant PK2 $(\times)$, mutant PK3 (crosses), and mutant PK4 (crosses), with NAcWW1 peptide, in buffer A, pH 6.0. Excitation was at $298 \mathrm{~nm}$, and emission was at $340 \mathrm{~nm}$, except PK3 (crosses) where emission was at $350 \mathrm{~nm}$. The data were fit to Equation 1, to give dissociation constants $\left(K_{d}\right)$ of $188 \mu \mathrm{M}$ for wild-type, $102 \mu \mathrm{M}$ for mutant 3 (also PK1), $37 \mu \mathrm{M}$ for mutant PK2, $3.3 \mu \mathrm{M}$ for mutant PK3, and $98 \mu \mathrm{M}$ for mutant PK4.
This mutant was obtained in the absence of proteinase $\mathrm{K}$ and at low concentration of protease. The tightest binding mutants, PK2 and PK3, obtained with $0.013 \mu \mathrm{g} / \mathrm{mL}$ proteinase $\mathrm{K}$, have $K_{d} \mathrm{~s}$ of 37 and $3.3 \mu \mathrm{M}$, respectively. Interestingly, these two clones show the most divergent spectral properties, compared to the wild-type protein. Mutant PK4, obtained with $0.13 \mu \mathrm{g} / \mathrm{mL}$ proteinase $\mathrm{K}$, has a $K_{d}$ of $98 \mu \mathrm{M}$.

A previous study gave a $K_{d}$ for wild-type of $52 \mu \mathrm{M}$ at $\mathrm{pH} 7.2$, with the peptide WW1 (Macias et al., 1996), whereas our results gave a $K_{d}$ of $188 \mu \mathrm{M}$ at $\mathrm{pH} 6.0$, with the peptide NAcWW1. This difference may be due to the difference in $\mathrm{pH}$, or the fact that our peptide was $\mathrm{N}$-acetylated. Another possible reason may be the different boundaries selected for the WW domain. Our domain consists of residues E6 to S57, whereas S4 to S57 preceded by Gly-Ser-Met was used in the previous study. However, this discrepancy is not important in this study, since we only wish to compare wild-type and the mutants under the same conditions.

\section{Thermal unfolding monitored by $C D$}

The thermal unfolding monitored by $\mathrm{CD}$ at $230 \mathrm{~nm}$ is shown for all of the WW domains in Figure 9. Clones 3 (also PK1) and PK4 (Fig. 9A) show cooperative transitions, similar to the wild-type WW domain. PK4, which was obtained at the highest concentration of proteinase $\mathrm{K}(0.13 \mu \mathrm{g} / \mathrm{mL})$, has a $T_{m}$ of $\sim 2{ }^{\circ} \mathrm{C}$ higher than wild-type WW. The $T_{m}$ of mutant 3 is very close to that of wildtype. Clones 1, PK2, and PK3, obtained with $0,0.013$, and $0.013 \mu \mathrm{g} / \mathrm{mL}$ proteinase $\mathrm{K}$, respectively, have noncooperative thermal unfolding transitions (Fig. 9B).

\section{Discussion}

We have used a phage display library of the WW domain to probe the specificity determinants of the WW domain for group I ligand 

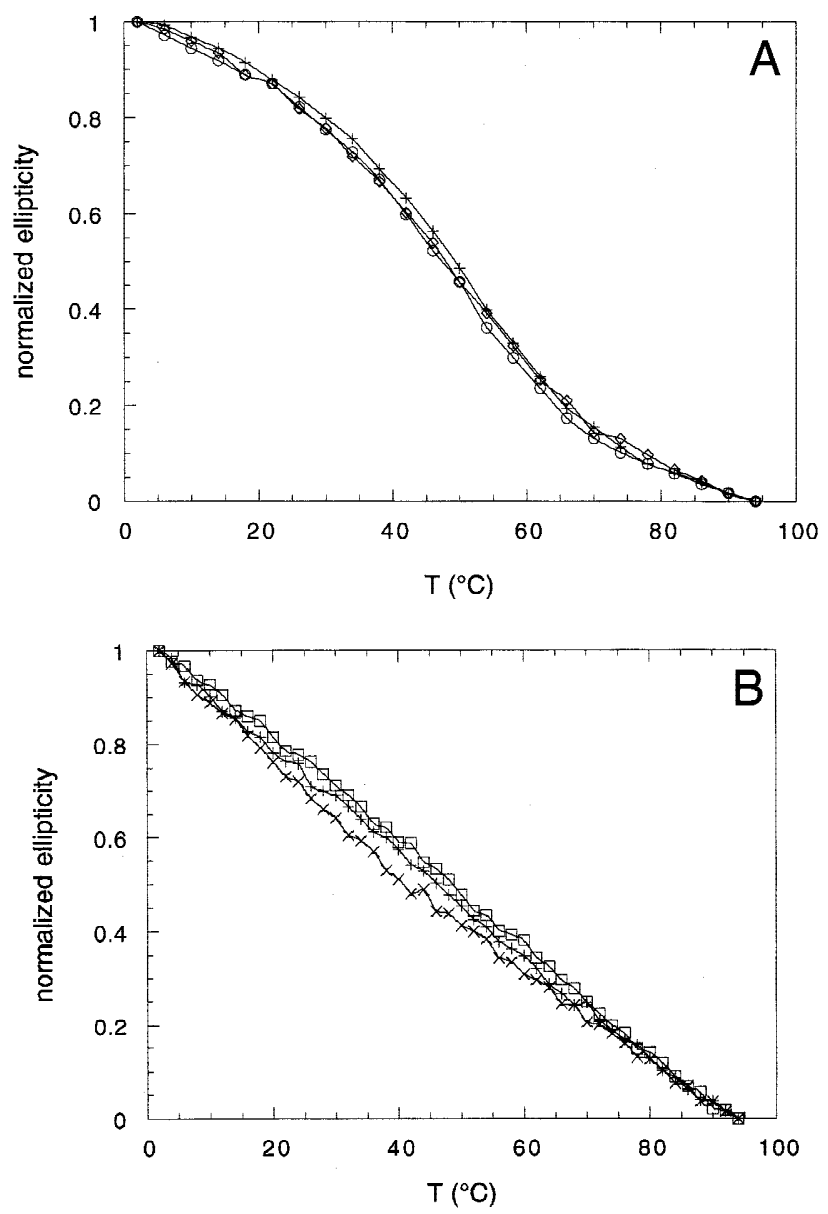

Fig. 9. Thermal unfolding monitored by $\mathrm{CD}$ at $230 \mathrm{~nm}$. A: Cooperatively folding proteins: wild-type WW (O), mutant 3 (also PK1) ( $\diamond)$, and mutant PK4 $(\triangle)$, in buffer A, $\mathrm{pH}$ 6.0. B: Uncooperative unfolding proteins: mutant $1\left(\_\right)$, mutant PK2 $(\times)$, and mutant PK3 (+), in buffer A, pH 6.0.

binding. Selection experiments were performed by biopanning against the immobilized peptide WW1, at three different concentrations of proteinase $\mathrm{K}(0,0.013$, and $0.13 \mu \mathrm{g} / \mathrm{mL})$. The additional selection pressure of proteinase $\mathrm{K}$ was aimed, in part, to probe for the determinants of protein stability as well as binding. It was expected that the determinants of binding, stability, and folding in the WW domain would be highly interdependent due to its small size.

Mutants 1,2 , and 3 were isolated at $0 \mu \mathrm{g} / \mathrm{mL}$ proteinase $\mathrm{K}$. However, binding data could be obtained only for mutant 3, which showed a value of $K_{d}$, of $102 \mu \mathrm{M}$. Mutants isolated at $0.013 \mu \mathrm{g} / \mathrm{mL}$ protease have up to a 60 -fold lower $K_{d}$ than the wild-type protein. Somewhat surprisingly, the mutant isolated at the highest concentration of proteinase $\mathrm{K}$ had a dissociation constant for NAcWW1 that was only approximately twofold lower than wild-type.

The increase in affinity against the peptide WW1 demonstrates that the wild-type WW domain is not optimized for binding to the GTPPPPYTVG sequence. Similarly, previous investigations have shown that natural ligands are not necessarily optimized for binding to a given WW domain (Nguyen et al., 1998). For example, optimizations of the ligand sequence, GTPPPPYTVG, using the SPOTs technique, and phage display of variants of the peptide, determined the new core-binding motif PPPPYP, with a dissociation constant for CTPPPPYPKG of $7.1 \mu \mathrm{M}$ (Linn et al., 1997). These differences demonstrate the importance of residues surrounding the PPPPY ligand sequence in altering the dissociation constant for complex formation. This may play an important role in the function of the WW domain, allowing it to bind several targets despite their different expression levels in the cell.

\section{Analysis of the hairpin sequences}

The structures of the ligand-binding sites of each selected sequence are shown schematically in Figure 10 (assuming conservation of the structure in the mutants). In all but one of the sequences, we observed a Trp at position 35. In the single exception (mutant 1), there is a Gly residue at position 35 and a Trp at position 34 . The flexibility of the glycine residue might allow an altered conformation of the loop, resulting in the ability of Trp34 to make contacts with the ligand upon binding. The structure of the randomized hairpin in the wild-type WW domain contains a fourresidue loop, where residues $32,33,34$, and 35 are in $\alpha_{r}, \alpha_{r}, \alpha_{r}$, and $\alpha_{L}$ conformations, respectively ( $\pi$-turn motif). Interestingly, Trp is almost invariant in the last loop position in our mutants. In
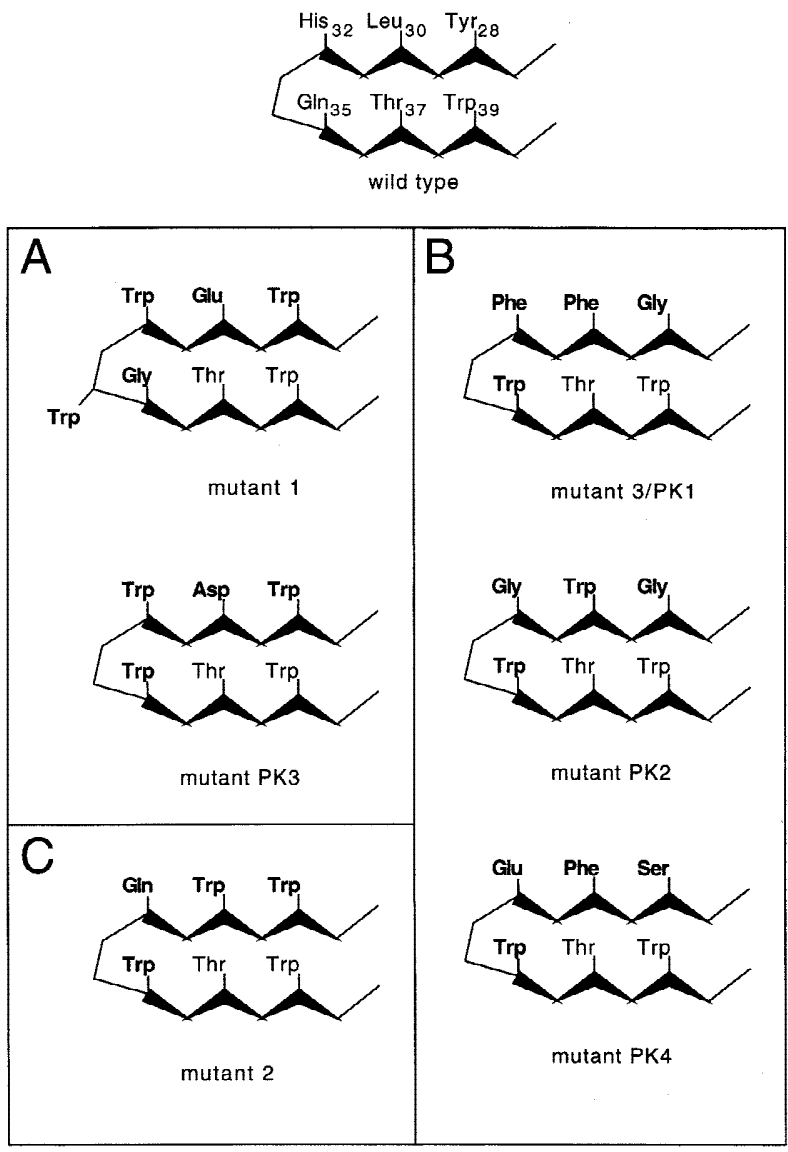

Fig. 10. Schematic representation of the structures of wild-type hYAP WW domain and the mutants. Only the residues involved in binding to the ligand are shown. Residues selected from the random library are shown in bold text. Wild-type residues are shown in plain text. The mutants are grouped into the potential consensus sequences A and B. Mutant 2 (Box C) is a hybrid of the two consensus sequences $\mathrm{A}$ and $\mathrm{B}$. 
natural proteins, often Gly is observed at this position to stabilize the $\alpha_{L}$ conformation (Rajashankar \& Ramakumar, 1996; Gunasekaran et al., 1997), although other interactions can override this local conformational preference. For example, Gly was not observed at this position in a previous genetic study of a $\pi$-turn motif in the B1 IgG-binding domain, which selected for loops of optimal ligandbinding and thermodynamic stability (Zhou et al., 1996). This finding indicated that the interactions formed by the amino acid side chain at this position more than compensated for the conformational destabilization associated with adopting unfavorable $\phi$ and $\psi$ angles.

Another conserved feature in the sequences of $\pi$-turns involves the residue immediately preceding the first residue of the loop (position 31). The first three residues of the loop approximate almost a full turn of an $\alpha$-helix. As a result, the preceding residue in the turn has a preference for side chains that can form a classical N-cap motif, namely Asn, Asp, Ser, Thr, or Gly (Richardson \& Richardson, 1988). In the above-mentioned study of the B1 IgG domain, the helix-capping residues Asp and Ser were most commonly selected in the position preceding the loop (Zhou et al., 1996). At this position in our sequences (residue 31), we observe a Gly, Ser, Ser, and His in mutants 1, PK3, 2, and PK2, respectively. This observation suggests that the structure of the $\beta$-hairpin may be largely retained in these mutants.

Consideration of the residues involved in ligand binding allows us to identify two possible consensus sequences obtained in the selection experiments (Table 2). Mutants 1 and PK3 comprise class A, with the residues Trp, Glu/Asp, and Trp at positions 28, 30, and 32, respectively. A second class (class B) includes mutants PK2, PK4, and 3/PK1, we observe a small residue (Gly or Ser) at position 28 , an aromatic at position 30 and a variable residue at position 32. The remaining mutant, 2, appears to be a hybrid of the above two potential consensus sequences, with a Trp at both positions 28 and 30 .

Overall, the WW mutants show a strikingly large number of Trp residues, which generally segregate to the binding surface. Figure 11 shows the $\log$ of the dissociation constants of the WW domains plotted against the number of tryptophan residues displayed on the binding surface of the protein. The data are linearly

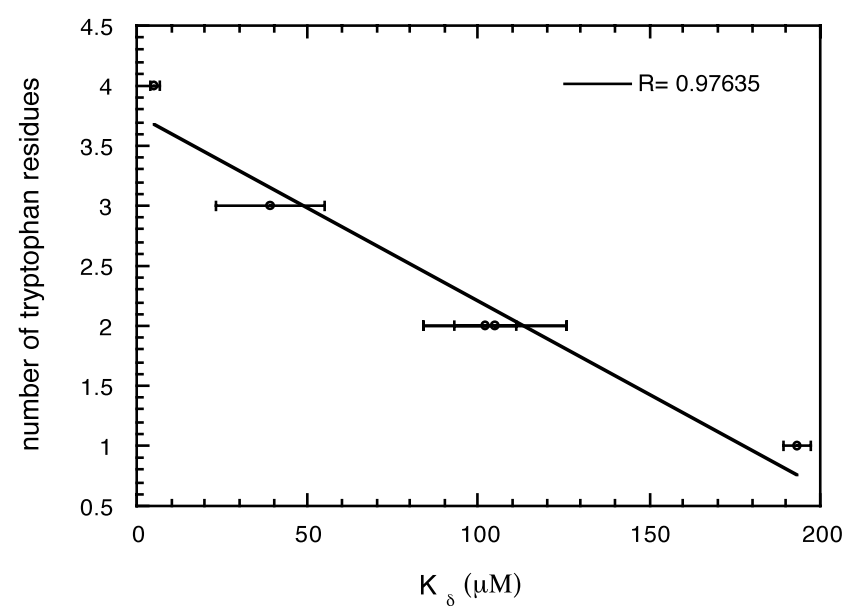

Fig. 11. Dependence of the number of tryptophan residues selected in the WW domain, on the dissociation constants for binding to the NAcWW1 peptide in buffer A, at $\mathrm{pH} 6.0$. correlated, with an increase in the number of tryptophan residues resulting in a decrease in the dissociation constant.

The sequences of typical WW domains representing several distinct groups are shown in Table 3. Comparison to the isolated sequences in Table 1 shows that our two potential consensus sequences that bind to the WWI peptide are distinct from any known naturally occurring WW domains. Interestingly, mutant 2 contains two consecutive aromatic residues on the binding surface, at residues 28 and 30. This is a characteristic of WW domains that bind to the group II motif (PPLP) (Espanel \& Sudol, 1999) and therefore suggests that the binding specificity of mutant 2 might be primarily directed towards the PPPP stretch of the WW1 peptide sequence.

\section{Conformational stability and binding affinity}

One of the goals of this paper was to assess the use of proteases to simultaneously select for affinity as well as conformational stability. The inclusion of protease led to a small decrease in the number of rounds of panning that was required to select binders. Also, intermediate concentrations of protease led to the selection of the mutants with the highest affinity for the WW1 peptide. However, it is interesting to note that the proteins with the highest affinity for the WW1 peptide lacked cooperative thermal unfolding transitions. The lack of a cooperative unfolding transition has classically been attributed to the protein adopting an entropically stabilized ensemble of states, rather than a single native conformation. Thus, the highest affinity binders may, in fact, lack conformational specificity in the absence of ligand.

\section{Conclusions}

Using phage display, it has been possible to identify new sequences that bind the WW1 sequence. Further, CD spectroscopy suggests that the mutant proteins are folded, as expected from the protease selection step. Thermal unfolding studies indicate that the same sequences unfold cooperatively with midpoints similar to that of the wild-type protein while other variants show noncooperative transitions, possibly indicative of more loosely folded states. Two sequence motifs appear to emerge from an analysis of the binding surface of the mutagenized hairpin, neither of which has a precedent in natural WW domains. Thus, the natural binding motifs found in nature appear to be far from unique solutions to the binding problem, and there may be a variety of ways to recognize polyproline domains within this framework. Indeed, very recent structural studies have revealed that WW domains can bind the Pro-rich peptides in one of two distinct binding orientations (Verdecia et al., 2000). It will be interesting to similarly investigate the mode of binding of the WW variants with poly-Pro peptides.

\section{Materials and methods}

\section{Media, chemicals, and enzymes}

Restriction enzymes and T4 DNA ligase were from Life Technologies, Inc. (Gaithersburg, Maryland) or New England Biolabs (Beverly, Massachusetts). Trifluoroacetic acid (TFA), thioanisole, anisole, ethanedithiol, bovine serum albumin (BSA), Tween-20, and proteinase K were from Sigma (St. Louis, Missouri). Thrombin was from Amersham-Pharmacia Biotech (Uppsala, Sweden). 
Table 3. Sequence alignment of selected WW sequences

\begin{tabular}{|c|c|c|}
\hline Host protein ${ }^{\mathrm{a}}$ & Sequence $^{\mathrm{b}}$ & Group $^{c}$ \\
\hline YAP 65 HUMAN & PLPAGWEMAKTSSGQRYFLNHIDQTTTWQDPR & $I^{d}$ \\
\hline YAP 65 MOUSE & PLPAGWEMAKTSSGQRYF LNHNDQTTTWQDPR & $I^{d}$ \\
\hline YAP 65 CHICK & PLPP GWEMAKTP SGQRYF LNH IDQTTTWQDPR & $I^{d}$ \\
\hline WWP 1 HUMAN & PLPEGWEIRYTREGVRYFVDHNTRTTTFKDPR & $\mathrm{I}^{\mathrm{e}}$ \\
\hline RSP 5 YEAST & PLPSGWEMRLTNTARVYFVDHNTKTTTWDDPR & \\
\hline PUB1 SCHPO & PLPSGWEMRLTNTARVYFVDHNTKTTTWDDPR & \\
\hline PRP 40 YEAST & ....WWEAKDASGRIYYYNTLTKKSTWEKPK & \\
\hline DMD CHICK & ....WERAISPNKVPYYINHETQTTCWDHPK & \\
\hline DMD HUMAN & . . . .WERAISPNKVPYYINHETQTTCWDHPK & \\
\hline DMD MOUSE & $\ldots \ldots$ WERAISPNKVPYY INHETQTTCWDHPK & \\
\hline DRP 2 HUMAN & . . . .WERAISPNKVPYYINHQAQTTCWDHPK & \\
\hline PIN1 HUMAN & LPP GWEKRMSRS SGRVYYFNH I TNASQWERP. & $I^{f}$ \\
\hline DODO DROME & LPDGWEKRTSRSTGMSYYLNMYTKESQWDQP . & \\
\hline YA12 SCHPO & PLPP GWTEHKAP SG IPYYWNAELKKSTYQRP. & \\
\hline UTRO HUMAN & ....WWRS ISHNKVPYY INHQTQTTCWDHPK & \\
\hline NEDD 4 HUMAN & . LPKGWEVRHAPNGRPF F IDHNTKTTTWEDPR & \\
\hline NEDD 4 HUMAN & PLPPGWEERQD I LGRTYYVNHESRRTQWKRP. & \\
\hline NEDD 4 MOUSE & PLPP GWEERTHTDGRVFF INHNI KKTQWEDPR & $\mathrm{IV}^{\mathrm{f}} / \mathrm{I}$ \\
\hline NEDD 4 MOUSE & . LPPGWEEKQDDRGRSYYVDHNSKTTTWSKP. & $\mathrm{IV}^{\mathrm{f}} / \mathrm{I}$ \\
\hline FE65 RAT & . LPAGWMRVQDTSG . TYYWHIPTGTTQWEPP . & $\mathrm{II}^{\mathrm{g}} / \mathrm{V}^{\mathrm{h}}$ \\
\hline FBP 21 HUMAN & ....WVEGITSEGYHYYYDLISGASQWEKPE & $\mathrm{III}^{\mathrm{i}} / \mathrm{V}^{\mathrm{h}}$ \\
\hline FBP30 MOUSE & ....WWEVWDENTGCYYYWNTQTNEVTWELP & $\mathrm{V}^{\mathrm{h}}$ \\
\hline
\end{tabular}

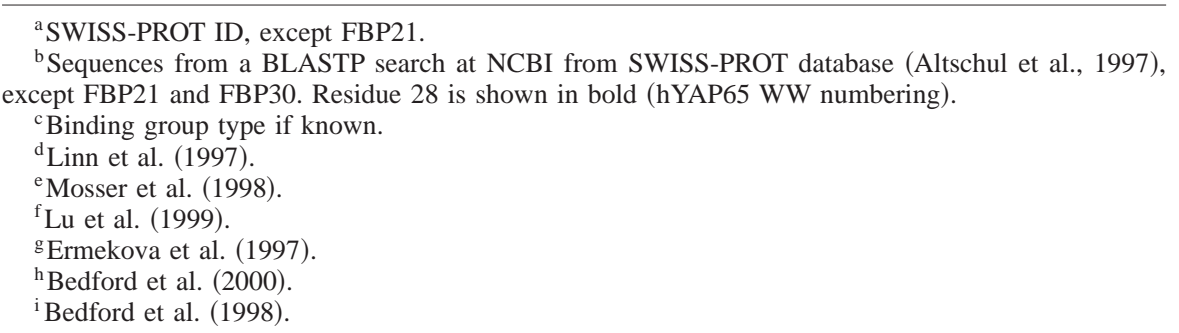

pfuTurbo $^{\mathrm{TM}}$ was from Stratagene (La Jolla, California). Fmocamino acids were from NovaBiochem (Switzerland). Reacti-Bind ${ }^{\mathrm{TM}}$ Streptavidin coated wells and EZ-link ${ }^{\mathrm{TM}}$ NHS-SS-Biotin were from Pierce (Rockford, Illinois). Tris-buffered saline (TBS) was made from $50 \mathrm{mM}$ Trizma base (Sigma), $150 \mathrm{mM} \mathrm{NaCl}$ (Sigma), adjusted to $\mathrm{pH} 7.0$ with $\mathrm{HCl}$.

\section{M13PL9WW phage construction}

The M13PL9 phage vector is a modified version of M13PL6 (O'Neil et al., 1992) in which the Bst XI restriction site has been replaced with a unique BamHI restriction site (R.H. Hoess, unpubl. data). The M13PL9 dsDNA was prepared by standard methods, as described (Sambrook et al., 1989). The hYAP WW gene (residues E6 to S57), which contains an amber stop-codon (TAG) at Y28, was synthesized by polymerase chain reaction (PCR), using the primers: WWA6, 5'-TCA GCC ATG GAG ATC CCA GAC GAC GTT CCA CTG CCG GCT GGT TGG GAA ATG GCT AAA ACT AGT TCT GGT CAG CGT-3'; WWA2, 5'-GTC CTG CCA CGT GGT GGT CTG GTC GAT GTG GTT CAG GAA CTA ACG CTG ACC AGA ACT AGT-3'; WWA3, 5'-ACC ACC ACG TGG CAG GAC CCG CGT AAA GCT ATG CTG TCT CAG ATG AAC GT-3'; WWA4, 5'-G TAA CTG AGC CAT GGC AGA GGT CGG AGC GGT AAC GTT CAT CTG AGA CAG C-3'.
The restriction sites and N-terminal signal sequence of gene III were then added by PCR, using the primers: KpnWW, 5'-C TAC GTC TAG GTA CCT TTC TAT TCT CAC TCC GAG ATC CCA GAC GAC GTT CCG-3', and BamHWW, 5'-AGT AAG CAC GGA TCC ACC ACC AGA GGT CGG AGC GGT AAC GTT C-3', to give the final construct: KpnI-WW-BamHI, 5'-C TAC GTC TAG GTA CCT TTC TAT TCT CAC TCC GAG ATC CCA GAC GAC GTT CCG CTG CCG GCT GGT TGG GAA ATG GCT AAA ACT AGT TCT GGT CAG CGT TAG TTC CTG AAC CAC ATC GAC CAG ACC ACC ACG TGG CAG GAC CCG CGT AAA GCT ATG CTG TCT CAG ATG AAC GTT ACC GCT CCG ACC TCT GGT GGT GGA TCC GTG CTT ACT-3'.

The KpnI-WW-BamHI construct and M13PL9 dsDNA were digested by Kpn I and Bam HI, ligated by T4-ligase, and then transformed into electrocompetent LE392 $\left(\mathrm{Kan}^{\mathrm{r}}\right)$ E. coli. The LE392 strain suppresses the amber stop-codon (TAG) at Y28 in the WW domain, allowing the translation of the whole gIII fusion, and subsequently allowing phage growth. The transformation mix was then amplified in LB medium containing $10 \mu \mathrm{g} / \mathrm{mL}$ kanamycin, for $4.5 \mathrm{~h}$ at $37^{\circ} \mathrm{C}$. Cells were removed by centrifugation, and the phage purified by precipitation with PEG8000 and $\mathrm{NaCl}$ as described (Smith, 1988). The M13PL9WW phage were resuspended in $1 \times$ PBS, filtered, and stored at $4{ }^{\circ} \mathrm{C}$. M13PL9WW dsDNA (Fig. 1A) was prepared from the pelleted cells as described (Sam- 
brook et al., 1989) and used to verify the construct by DNA sequencing.

\section{Random mutagenesis of WW}

The randomized oligonucleotide, (WWR9) 5'-T AAA ACT AGT TCT GGT CAG CGT NNS NNS NNS NNS NNS NNS NNS NNS ACC ACC ACG TGG CAG GAC CCG CGT-3' (where N indicates a mixture of $25 \%$ of each base, and $\mathrm{S}$ indicates a mixture of $50 \%$ $\mathrm{C}$ and $50 \% \mathrm{G}$ ), was amplified by 7 cycles of PCR, using the primers (WWR10) 5'-T AAA ACT AGT TCT GGT CAG CGT-3', and (WWR11) 5'-ACG CGG GTC CTG CCA CGT GGT GGT-3'. The resulting double-stranded DNA was digested with Spe I and Pml I, purified using a PCR purification kit (Qiagen, Germany), and ligated as above into a similarly digested M13PL9WW phage construct. To construct the phage library, fourteen $200 \mu \mathrm{L}$ aliquots of K91 cells were each electroporated with $7.1 \mu \mathrm{L}$ ligation product (diluted 1:4 in $\mathrm{dd}_{2} \mathrm{O}$ ), then diluted to $1 \mathrm{~mL}$ with SOC (Sambrook et al., 1989). After $1 \mathrm{~h}$ at $37^{\circ} \mathrm{C}$, a small aliquot was removed to estimate the size of the library, and the remaining culture was diluted to $200 \mathrm{~mL}$ with $\mathrm{LB}$ medium, and shaken at $37^{\circ} \mathrm{C}$ for an additional $4 \mathrm{~h}$. Cells were removed by centrifugation, and the phage purified by precipitation with PEG8000 and $\mathrm{NaCl}$ as described (Smith, 1988). The phage library was resuspended in blocking buffer (50 mM Tris.Cl pH 7.0, $150 \mathrm{mM} \mathrm{NaCl}, 1 \mathrm{mg} / \mathrm{mL}$ BSA, $0.05 \%$ Tween-20, $0.02 \% \mathrm{NaN}_{3}$ ), filtered, and stored at $4{ }^{\circ} \mathrm{C}$. The polyclonal phage library was sequenced as above to verify randomization.

\section{M13WWSIP phage construction}

The hYAP WW gene (residues E6 to S57), which contains an amber stop-codon (TAG) at Y28 and Nco I sites at both the $\mathrm{N}$ - and C-termini, was synthesized by PCR as described above, using the primers WWA6, WWA2, WWA3, and WWA4.

An Nco I restriction site was introduced into the M13mp18 phage vector, in the linker between the $\mathrm{N}$ - and $\mathrm{C}$-terminal domains, using the site directed mutagenesis kit Quikchange (Stratagene), and the primers (NcoIF) 5'-GGC TCT GGT TCC ATG GAT TTT GAT T-3' and (NcoIR) 5'-A ATC AAA ATC CAT GGA ACC AGA GCC-3'. The Nco I-WW-Nco I construct and M13mp18(Nco I) dsDNA were digested by Nco I, ligated by T4-ligase, and then transformed into electrocompetent LE392 $\left(\operatorname{Kan}^{\mathrm{r}}\right)$ E. coli. The transformation mix was then amplified in $\mathrm{LB}$ medium containing $10 \mu \mathrm{g} / \mathrm{mL}$ kanamycin, for $4.5 \mathrm{~h}$ at $37^{\circ} \mathrm{C}$. Cells were removed by centrifugation, and the phage purified by precipitation with PEG8000 and $\mathrm{NaCl}$ as above. The M13WWSIP phage were resuspended in $1 \times$ PBS, filtered, and stored at $4{ }^{\circ} \mathrm{C}$. M13WWSIP dsDNA (Fig. 1B) was prepared from the pelleted cells as described above and used to verify the construct by DNA sequencing.

\section{Peptide synthesis}

Peptides were synthesized by standard Fmoc procedures, using an ABI 433A solid phase synthesizer. The crude WW1 peptide (GTPPPPYTVG) was obtained by deprotection and cleavage from the resin with a standard mixture of TFA, thioanisole, anisole, and ethanedithiol. Crude NAcWW1 was obtained by acetylating the N-terminally deprotected WW1 peptide on the resin under standard conditions, prior to TFA cleavage. Both peptides were purified by reversed-phase high-performance liquid chromatography followed by lyophilizing, and confirmed by MALDI-TOF and ES mass spectroscopy.

Biotinylated WW1 peptide (EZWW1) was obtained by incubating 1 eq. WW1 with 1.5 eq. EZ-link NHS-SS-biotin (Pierce), in $200 \mu \mathrm{L} 100 \mathrm{mM}$ sodium phosphate buffer, $\mathrm{pH}$ 8.0, for $1 \mathrm{~h}$. EZWW1 was then purified and confirmed, as above.

Peptide concentrations were determined by measuring their absorbance at $280 \mathrm{~nm}$ in $6 \mathrm{M}$ guanidinium chloride $(\mathrm{GdmCl})$, and assuming an extinction coefficient of $1,285 \mathrm{M}^{-1} \mathrm{~cm}^{-1}$ for the tyrosine residue as described (Pace et al., 1995).

\section{Recovery of M13WWSIP phage under different protease conditions}

Approximately $10^{12} \mathrm{pfu} / \mathrm{mL}$ M13WWSIP phage, or wild-type phage (M13mp18), both in the presence and absence of $100 \mu \mathrm{M}$ WW1, were incubated for $15 \mathrm{~min}$ at $4{ }^{\circ} \mathrm{C}$, with either: (1) $\mathrm{ddH}_{2} \mathrm{O}$; (2) $0.13 \mu \mathrm{g} / \mathrm{mL}$ proteinase $\mathrm{K}, 50 \mathrm{mM}$ Tris $\cdot \mathrm{Cl}, 100 \mathrm{mM} \mathrm{NaCl}$, $2 \mathrm{mM} \mathrm{Ca}(\mathrm{OAc})_{2}$, pH 8.0; (3) $0.147 \mu \mathrm{g} / \mathrm{mL}$ papain, $50 \mathrm{mM}$ glutamic acid, $100 \mathrm{mM} \mathrm{NaCl}, 1 \mathrm{mM} \mathrm{CaCl}_{2}, \mathrm{pH} 6.6$; or (4) $100 \mu \mathrm{g} / \mathrm{mL}$ subtilisin A, $50 \mathrm{mM}$ Tris $\cdot \mathrm{Cl}, 100 \mathrm{mM} \mathrm{NaCl}, 1 \mathrm{mM} \mathrm{CaCl}_{2}, \mathrm{pH}$ 7.5. Both the input and digested phage samples were serial diluted in LB medium, and plated with K91 cells, on LB agar, to determine the number of infectious phage in each sample. The fraction of phage recovered, expressed as a percentage, were normalized to the $\mathrm{ddH}_{2} \mathrm{O}$ experiment (Fig. 4), as each protease required very different buffers.

Titration of M13WWSIP phage with WW1 peptide, in the presence of proteinase $K$

Approximately $10^{12} \mathrm{pfu} / \mathrm{mL}$ M13WWSIP phage, in the presence of either $0,25,50,75$, or $100 \mu \mathrm{M}$ WW1, were incubated for $15 \mathrm{~min}$ at $4{ }^{\circ} \mathrm{C}$, in the presence of $0.13 \mu \mathrm{g} / \mathrm{mL}$ proteinase $\mathrm{K}$, $50 \mathrm{mM}$ Tris $\cdot \mathrm{Cl}, 100 \mathrm{mM} \mathrm{NaCl}, 2 \mathrm{mM} \mathrm{Ca}(\mathrm{OAc})_{2}, \mathrm{pH}$ 8.0. The input and digested phage samples were each serial diluted and plated as above, to determine the number of infectious phage in each sample.

\section{Biopanning procedure}

Streptavidin coated wells were incubated overnight at $4{ }^{\circ} \mathrm{C}$, with $300 \mu \mathrm{L}$ of a $2 \mu \mathrm{M}$ solution of EZWW1 in blocking buffer. Any remaining streptavidin sites were blocked with $1 \mathrm{mM}$ biotin in wash buffer (TBS/0.05\% Tween-20) for $15 \mathrm{~min}$ at room temperature, then washed three times with wash buffer. Wells were incubated with $50 \mu \mathrm{L}$ of phage, by rocking for $2 \mathrm{~h}$ at room temperature. The wells were then placed at $4{ }^{\circ} \mathrm{C}$, and $116 \mu \mathrm{L}$ of proteinase $\mathrm{K}$ buffer $\left(143 \mathrm{mM} \mathrm{NaCl}, 71.5 \mathrm{mM}\right.$ Tris $\cdot \mathrm{Cl}, 2.86 \mathrm{mM} \mathrm{Ca}(\mathrm{OAc})_{2}$, $\mathrm{pH} 8.0$ ) containing $0.185,0.0185$, or $0 \mu \mathrm{g} / \mathrm{mL}$ proteinase $\mathrm{K}$, was added and incubated for $15 \mathrm{~min}$ at $4{ }^{\circ} \mathrm{C}$. Wells were then washed eight times with wash buffer, and the bound phage eluted with two $50 \mu \mathrm{L}$ aliquots of $20 \mathrm{mM}$ reduced DTT in wash buffer, for $5 \mathrm{~min}$ each, at room temperature. The recovery of phage was determined by serial dilution and plating with K91 cells, of both the eluted phage, and the input phage. The eluted phage were also amplified in $40 \mathrm{~mL}$ LB medium with $100 \mu \mathrm{L} \mathrm{K91} \mathrm{cells,} \mathrm{and} \mathrm{prepared} \mathrm{as}$ above for subsequent rounds of biopanning. Ten isolated plaques from each experiment were amplified and sequenced after the sixth round of biopanning. 


\section{Protein expression and purification}

The restriction sites for Bam $\mathrm{HI}$ and Hind III were introduced, respectively, to the $5^{\prime}$ and $3^{\prime}$ ends of each new WW gene, by PCR. The primers used were: 5BamHIWW, 5'-ATC AAG ACT GGA TCC GAG ATC CCA GAC GAC GTT CCG-3', and 3HindIIIWW, 5'-TGT GAT CTA AGC TTA AGA GGT CGG AGC GGT AAC GTT-3'. The new genes were digested with Bam HI and Hind III, purified as above, and ligated into a similarly digested pGAT2 vector (Koepf et al., 1999). Each construct was then transformed into BL21DE3 cells (Stratagene), and then their DNA sequenced using a standard GST primer. The GST-WW fusion proteins were expressed and the purified WW domains obtained as described (Koepf et al., 1999). Protein concentrations were determined by measuring their absorbance at $280 \mathrm{~nm}$ in $6 \mathrm{M}$ guanidinium chloride $(\mathrm{GdmCl})$, and assuming an extinction coefficients of (wt) $12,655 \mathrm{M}^{-1} \mathrm{~cm}^{-1}$, (1) $28,425 \mathrm{M}^{-1} \mathrm{~cm}^{-1}$, (3/PK1) 22,740 $\mathrm{M}^{-1} \mathrm{~cm}^{-1}$, (PK2) 28,425 $\mathrm{M}^{-1} \mathrm{~cm}^{-1}$, (PK3) 28,425 $\mathrm{M}^{-1} \mathrm{~cm}^{-1}$, (PK4) 17,055 $\mathrm{M}^{-1} \mathrm{~cm}^{-1}$, as described (Pace et al., 1995).

\section{Fluorescence spectra}

Fluorescence spectra were recorded at room temperature on a PBI Spectrofluorometer, using an excitation wavelength of $298 \mathrm{~nm}$, and detection from 450 to $300 \mathrm{~nm}$ at intervals of $1 \mathrm{~nm}$. Excitation and emission monochrometer slit widths were both set to $1.5 \mathrm{~mm}$. A $1.0 \times 1.0 \mathrm{~cm}$ Suprasil quartz cell (Hellma, New York) was charged with $5 \mu \mathrm{M} \mathrm{WW}$ domain in buffer A (10 mM potassium phosphate, $100 \mathrm{mM} \mathrm{NaCl}, 0.1 \mathrm{mM}$ EDTA, $0.1 \mathrm{mM}$ DTT, $0.02 \%$ $\mathrm{NaN}_{3}, \mathrm{pH}$ 6.0).

\section{Determination of $K_{d}$ by fluorescence}

The hyperbolic binding curve for $5 \mu \mathrm{M}$ WW domain in buffer A, titrated manually with a $10 \mathrm{mM}$ solution of NAcWW1 in buffer A, was obtained by monitoring changes in fluorescence as described (Koepf et al., 1999). Data were recorded at room temperature, as above, using an excitation wavelength of $298 \mathrm{~nm}$, and detection at 340 or $350 \mathrm{~nm}$. For each titration, the solution was mixed and equilibrated for $2 \mathrm{~min}$. Each data point was averaged over a $10 \mathrm{~s}$ period, and each binding curve was repeated at least three times.

The dissociation constant $K_{d}$ for each protein was obtained by fitting the fluorescence data in Kaleidagraph (Synergy Software) to the hyperbolic function:

$$
F=F_{f}+\left(F_{b}-F_{f}\right)\left[\operatorname{Ligand}_{f}\right] /\left(K_{d}+\left[\operatorname{Ligand}_{\mathrm{f}}\right]\right)
$$

where $F$ is the total fluorescence, $F_{f}$ is the fluorescence of the unbound WW domain, $F_{b}$ is the fluorescence of the WW-ligand complex, and $\left[\right.$ Ligand $\left._{f}\right]$ is the free ligand concentration (Viguera et al., 1994).

\section{Circular dichroism spectroscopy}

CD studies were performed using an AVIV Model 62A DS Circular Dichroism Spectrometer (Lakewood, New Jersey), with a peltier temperature-controlled cell holder. A $0.1 \mathrm{~cm}$ pathlength Suprasil quartz cell (Hellma, New York) was charged with $50 \mu \mathrm{M}$ WW domain in buffer $\mathrm{A}$ and equilibrated for $10 \mathrm{~min}$ at $25^{\circ} \mathrm{C}$. Far-UV wavelength scans were recorded at $25^{\circ} \mathrm{C}$, from 250 to $190 \mathrm{~nm}$ in $2 \mathrm{~nm}$ increments. A similar blank scan of just buffer A was recorded four times, and the average subtracted from the sample scans. The same sample was then used for thermal-induced unfolding from 2 to $94^{\circ} \mathrm{C}$, in increments of 2 or $4{ }^{\circ} \mathrm{C}$. Samples were equilibrated for $5 \mathrm{~min}$ at each temperature, and the $\mathrm{CD}$ signal at $230 \mathrm{~nm}$ was measured and averaged over $10 \mathrm{~s}$. The data were not fitted to a thermal-melting profile, due to the absence of useful preand post-transition baselines.

\section{Acknowledgments}

We thank the National Science Foundation and the Office of Naval Research for financial support, Steve Lahr for helpful discussions, and Prof. J.W. Kelly and Dr. E.K. Koepf for the generous gift of the pGAT2 vector.

\section{References}

Altschul SF, Madden TL, Schaffer AA, Zhang J, Zhang Z, Miller W, Lipman DJ. 1997. Gapped BLAST and PSI-BLAST: A new generation of protein database search programs. Nucleic Acids Res 25:3389-3402.

Bedford MT, Reed R, Leder P. 1998. WW domain-mediated interactions reveal a spliceosome-associated protein that binds a third class of proline-rich motif: The proline glycine and methionine-rich motif. Proc Natl Acad Sci USA 95:10602-10607.

Bedford MT, Sarbassova D, Xu J, Leder P, Yaffe MB. 2000. A novel pro-Arg motif recognized by WW domains. J Biol Chem 275:10359-10369.

Chen HI, Sudol M. 1995. The WW domain of Yes-associated protein binds a proline-rich ligand that differs from the consensus established for Src homology 3-binding modules. Proc Natl Acad Sci USA 92:7819-7823.

Ermekova KS, Zambrano N, Linn H, Minopoli G, Gertler F, Russo T, Sudol M. 1997. The WW domain of neural protein FE65 interacts with proline-rich motifs in Mena, the mammalian homolog of Drosophila enabled. J Biol Chem 272:32869-32877.

Espanel X, Sudol M. 1999. A single point mutation in a group I WW domain shifts its specificity to that of group II WW domains. J Biol Chem 274: 17284-17289.

Feng S, Chen JK, Yu H, Simon JA, Schreiber SL. 1994. Two binding orientations for peptides to the Src SH3 domain: Development of a general model for SH3-ligand interactions. Science 266:1241-1247.

Finucane MD, Woolfson DN. 1999. Core-directed protein design. II. Rescue of a multiply mutated and destabilized variant of ubiquitin. Biochemistry 38:11613-11623.

Gunasekaran K, Ramakrishnan C, Balaram P. 1997. Beta-hairpins in proteins revisited: Lessons for de novo design. Protein Eng 10:1131-1141.

Jung S, Honegger A, Pluckthun A. 1999. Selection for improved protein stability by phage display. J Mol Biol 294:163-180.

Koepf EK, Petrassi HM, Sudol M, Kelly JW. 1999. WW: An isolated threestranded antiparallel beta-sheet domain that unfolds and refolds reversibly; evidence for a structured hydrophobic cluster in urea and $\mathrm{GdnHCl}$ and a disordered thermal unfolded state. Protein Sci 8:841-853.

Krebber C, Spada S, Desplancq D, Krebber A, Ge L, Pluckthun A. 1997. Selectively-infective phage (SIP): A mechanistic dissection of a novel in vivo selection for protein-ligand interactions. J Mol Biol 268:607-618.

Kristensen P, Winter G. 1998. Proteolytic selection for protein folding using filamentous bacteriophages. Fold Des 3:321-328.

Lakshmikanth GS, Krishnamoorthy G. 1999. Solvent-exposed tryptophans probe the dynamics at protein surfaces. Biophys $J$ 77:1100-1106.

Liao H, Byeon IJ, Tsai MD. 1999. Structure and function of a new phosphopeptidebinding domain containing the FHA2 of Rad53. J Mol Biol 294:1041-1049.

Lim WA, Richards FM, Fox RO. 1994. Structural determinants of peptidebinding orientation and of sequence specificity in SH3 domains [see comments] [published Erratum appears in Nature, 1995, 374(6517):94]. Nature 372:375-379.

Linn H, Ermekova KS, Rentschler S, Sparks AB, Kay BK, Sudol M. 1997. Using molecular repertoires to identify high-affinity peptide ligands of the WW domain of human and mouse YAP. Biol Chem 378:531-537.

Lu PJ, Zhou XZ, Shen M, Lu KP. 1999. Function of WW domains as phosphoserine- or phosphothreonine-binding modules. Science 283:13251328.

Macias MJ, Gervais V, Civera C, Oschkinat H. 2000. Structural analysis of WW domains and design of a WW prototype. Nat Struct Biol 7:375-379.

Macias MJ, Hyvonen M, Baraldi E, Schultz J, Sudol M, Saraste M, Oschkinat H. 1996. Structure of the WW domain of a kinase-associated protein complexed with a proline-rich peptide. Nature 382:646-649.

Mosser EA, Kasanov JD, Forsberg EC, Kay BK, Ney PA, Bresnick EH. 1998. 
Physical and functional interactions between the transactivation domain of the hematopoietic transcription factor NF-E2 and WW domains. Biochemistry 37:13686-13695.

Nguyen JT, Turck CW, Cohen FE, Zuckermann RN, Lim WA. 1998. Exploiting the basis of proline recognition by $\mathrm{SH} 3$ and WW domains: Design of N-substituted inhibitors. Science 282:2088-2092.

O’Neil KT, Hoess RH, Jackson SA, Ramachandran NS, Mousa SA, DeGrado WF. 1992. Identification of novel peptide antagonists for GPIIb/IIIa from a conformationally constrained phage peptide library. Proteins Struct Funct Genet 14:509-515.

Pace CN, Vajdos F, Fee L, Grimsley G, Gray T. 1995. How to measure and predict the molar absorption coefficient of a protein. Protein Sci 4:2411-2423.

Pawson T, Scott JD. 1997. Signaling through scaffold, anchoring, and adaptor proteins. Science 278:2075-2080.

Rajashankar KR, Ramakumar S. 1996. Pi-turns in proteins and peptides: Classification, conformation, occurrence, hydration, and sequence. Protein Sci 5:932-946.

Ranganathan R, Lu KP, Hunter T, Noel JP. 1997. Structural and functional analysis of the mitotic rotamase Pinl suggests substrate recognition is phosphorylation dependent. Cell 89:875-886.
Richardson JS, Richardson DC. 1988. Amino acid preferences for specific locations at the ends of alpha helices [published Erratum appears in Science, 1988, 242(4886):1624]. Science 240:1648-1652.

Sambrook J, Fritsch EF, Maniatis T. 1989. Molecular cloning: A laboratory manual, 2nd edition. Cold Spring Harbor, New York: Cold Spring Harbor Laboratory Press.

Smith GP. 1988. Filamentous phage assembly: Morphogenetically defective mutants that do not kill the host. Virology 167:156-165.

Sudol M. 1998. From Src Homology domains to other signaling modules: Proposal of the "protein recognition code." Oncogene 17:1469-1474.

Verdecia MA, Bowman ME, Lu KP, Hunter T, Noel JP. 2000. Structural basis for phosphoserine-proline recognition by group IV WW domains. Nat Struct Biol 7:639-643.

Viguera AR, Arrondo JL, Musacchio A, Saraste M, Serrano L. 1994. Characterization of the interaction of natural proline-rich peptides with five different SH3 domains. Biochemistry 33:10925-10933.

Zhou HX, Hoess RH, DeGrado WF. 1996. In vitro evolution of thermodynamically stable turns. Nat Struct Biol 3:446-451.

Zhou S, Cantley LC. 1995. Recognition and specificity in protein tyrosine kinase-mediated signaling. Trends Biochem Sci 20:470-475. 